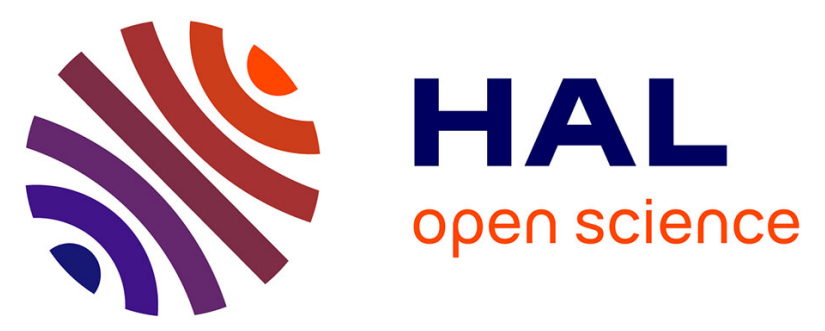

\title{
Phylogenetic relationships between genera Dorcadion, Lamia, Morimus, Herophila and some other Lamiinae (Coleoptera: Cerambycidae) based on chromosome and CO1 gene sequence comparison
}

Themis Giannoulis, Anne-Marie Dutrillaux, Constantina Sarri, Zissis Mamuris, Bernard Dutrillaux

\section{To cite this version:}

Themis Giannoulis, Anne-Marie Dutrillaux, Constantina Sarri, Zissis Mamuris, Bernard Dutrillaux. Phylogenetic relationships between genera Dorcadion, Lamia, Morimus, Herophila and some other Lamiinae (Coleoptera: Cerambycidae) based on chromosome and CO1 gene sequence comparison. Bulletin of Entomological Research, 2020, 110 (3), pp.321-327. 10.1017/S0007485319000737 . hal02968144

\author{
HAL Id: hal-02968144 \\ https://hal.science/hal-02968144
}

Submitted on 27 Oct 2020

HAL is a multi-disciplinary open access archive for the deposit and dissemination of scientific research documents, whether they are published or not. The documents may come from teaching and research institutions in France or abroad, or from public or private research centers.
L'archive ouverte pluridisciplinaire HAL, est destinée au dépôt et à la diffusion de documents scientifiques de niveau recherche, publiés ou non, émanant des établissements d'enseignement et de recherche français ou étrangers, des laboratoires publics ou privés. 
1 Phylogenetic relationships between genera Dorcadion, Lamia, Morimus, Herophila and . some other Lamiinae (Coleoptera: Cerambycidae) based on chromosome and CO1 gene sequence comparison

Themis Giannoulis 1, Anne-Marie Dutrillaux 2, Sarri Constantina 1, Zissis Mamuris 1, Bernard Dutrillaux 2

1 Laboratory of Genetics, Comparative and Evolution Biology, Department of biochemisty and Biotechnology, University of Thessaly 41221Larissa Greece

2 Institut de Systématique, Evolution, Biodiversité. ISYEB-UMR 7505-CNRS, MNHN, UMPC, EPHE. Muséum National d'Histoire Naturelle, Sorbonne Universités. 57, rue Cuvier, CP32. 75005 Paris France

Key Words: Lamiinae, CO1 sequencing, karyotype, phylogeny, monophyly.

\section{Short title: Monophyly of genera Dorcadion, Lamia, Herophila and Morimus}

\section{Summary}

A dual molecular and cytogenetic study was performed with the aim to improve the controversial systematic classification of some species of Lamiinae (Coleoptera: Cerambycidae). The karyotypes of species belonging to genera Morimus, Herophila, 3 Dorcadion, Neodorcadion and Lamia share a number of characters, which differentiate them

24 from other species, belonging to genera Phytoecia, Parmena and Monochamus. The 5 karyotypes of the last 3 species comprise 20 chromosomes, mostly metacentric or sub- 
metacentric, as in the presumed Cerambycidae ancestors. The karyotypes of the former species share many characters derived from the Lamiinae ancestors by a number of chromosome fissions and inversions indicating their monophyly. Comparisons of the CO1 gene sequence also show the monophyly of Morimus, Lamia, Herophila and Dorcadion and their distant relationship with others. These convergent results allow us to propose a phylogenetic classification of these genera, which places the monospecific genus Lamia close to Dorcadion, clearly separates Dorcadion and Neodorcadion and places Herophila closer to Morimus than to Dorcadion/Lamia. The genus Morimus is the most derived. CO1 mutations loosely separate the forms $M$. asper and M. funereus, which have similar karyotypes and behaviour and copulate in captivity. The form M. ganglebaueri may have a funereus X asper hybrid origin.

\section{Introduction}

Lamiinae constitute the largest sub-family of Cerambycidae, one of the largest families of Coleoptera. which form the largest order of the animal kingdom. Thus, with more than 21,000 species, Lamiinae represent one of the largest taxonomic animal entity. Latreille created this sub-family in 1825 and considered Lamia textor Linneaeus, 1758 for its type species. The genus Lamia remained mono-specific with L. textor for its single species and was included, in the tribe Lamiini Latreille, 1825. Other tribes, such as Dorcadionini Latreille, 1825, Agniini Thomson, 1864, Monochamini Thomson, 1860 and Phrissomini Thomson, 1860 were further created, and shared variously some of the species initially included in the Lamiini. Today, the general trends are either to transfer species belonging to Lamiini to Monochamini or include all Monochamini into Lamiini, but these changes are principally based upon the analysis of phenotypic characters (Bousquet et al. 2009, Lobl and Smetana, 2010, Monné et al., 2017). Beside Lamia, the genus Morimus Brullé, 1832 is composed of a small number of Palearctic 
species/sub-species, which have alternatively been classified into Lamiini or Phrissomini. Phrissomini were isolated from Lamiini to group apterous species but the present trend is to consider this distinction not valid. There is no more unanimity about the distribution of species into these tribes. In Europe, the number of recognized species of Morimus varies from 1 to 4 , depending on the elevation of three taxons (ganglbaueri, Reitter, 1884, verecundus, Falderman, 1836, and funereus, Mulsant, 1862) to the rank of species, or their classification as simple sub-species of $M$. asper Sulzer, 1776. About 10 other species occur in oriental regions. For the sake of simplification, we will arbitrarily call the taxa studied here $M$. asper, $M$. ganglbaueri and M. funereus, without presumption of the validity of their species status. The genus Morimus shares a number of morphological characters with the genus Herophila, Mulsant, 1863. Both are often included in the tribe Phrissomini. Their morphology recalls that of Lamia textor Linneaeus, 1758 and also that of species of Dorcadion Dalman, 1817 generally classified into Dorcadionini. Very few cytogenetic studies were performed (Smith and Virkki, 1978, Dutrillaux and Dutrillaux, 2011, Okutaner et al., 2011) and there is neither conclusions about the species status within genera, nor the phylogenetic relationships between genera. In a recent study of CO1 and ITS2 genes, developed on M. asper and M. funereus specimens from Italy, Croatia, Montenegro Slovenia, Turkey and Peloponnese, Solano et al. (2013) concluded that their genetic distance is small and compatible with the presence of a single species. The aim of our work was to provide genetic criteria for improving phylogenetic relationships and classification of genera Morimus, Lamia, Herophila and Dorcadion by the study and comparison of both their chromosomes and their CO1 gene sequence. For genus Morimus specimens from 2 unexplored regions, France and continental Greece were selected. Two of the 3 species of Herophila could also be studied. For genera Dorcadion/Neodorcadion, the systematic classification is so conflicting that we restricted our report on a few consensual species amongst the many species we studied. Species of 3 other 
genera of Lamiinae: Parmena (Parmenini), Monochamus Dejean, 1821 (Monochamini Gistel, 1848) and Phytoecia Mulsant, 1832 (Phytoeciini Mulsant, 1839); are used as outgroups.

\section{Material and Methods}

\section{Animals}

Morimus asper: male specimens from France, both sides of the Verdon river, near La Palud-

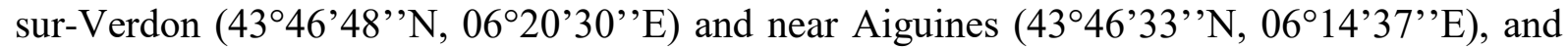
Greece, Tripi, near Sparti $\left(37^{\circ} 04^{\prime} 10^{\prime}\right.$ N, $2^{\circ} 16^{\prime} 20^{\prime} E$, Fig. 1 a) Peloponisos, near Metsovo

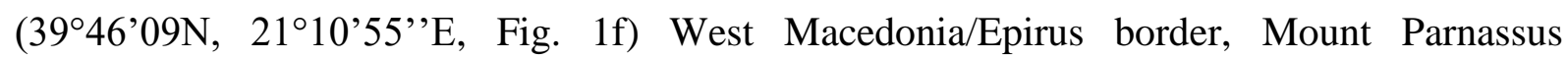
(38³3’09’N, 22³3'30’'E, Fig. 1d) Central Greece.

Morimus funereus: male specimens from Greece, Thessaly: Mount Ossa (3947’59’'N,

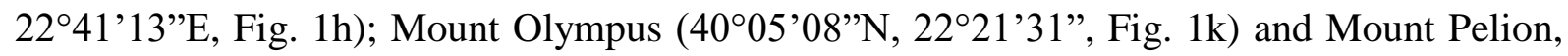
near Volos $\left(39^{\circ} 30^{\prime} \mathrm{N}, 2^{\circ} 57^{\prime} \mathrm{E}\right)$; West Macedonia: mount Pelister near Kastoria $\left(40^{\circ} 31^{\prime} \mathrm{N}\right.$, $21^{\circ} 18^{\prime}$ E, Fig. 1g); East Macedonia/Thrace bordure: Central Rodopi, Kariofito, near Stavropouli $\left(40^{\circ} 40^{\prime} \mathrm{N}, 22^{\circ} 56^{\prime} \mathrm{E}\right.$, Fig. $\left.1 \mathrm{j}\right)$.

Morimus ganglbaueri Reitter, 1894: One male and one female specimens from Bourazani, near Albanian border (4003'13’N, 20³7’36”'E, Fig. 11), Epirus, Greece.

Herophila tristis Linnaeus, 1767: male specimens from Greece, near Lake Prespa $\left(40^{\circ} 46^{`} \mathrm{~N}\right.$, $\left.21^{\circ} 06^{\prime} \mathrm{E}\right)$, West Macedonia and Bourazani (Fig.1n, o).

Herophila faimairei Thomson, 1857: female specimens from Mount Parnassus (Fig. 1p).

Lamia textor Linnaeus, 1758: one female from the south of France (Fig. 1s).

Dorcadion (Cribridorcadion) thessalicum Pic, 1916: males from Meteora region $\left(39^{\circ} 42^{\prime} \mathrm{N}\right.$, $21^{\circ} 37^{\prime} E$, Fig. 1t), Thessaly, Greece.

Dorcadion (Cribridorcadion) equestre Laxman, 1770: males from Ohrid region $\left(41^{\circ} 07^{\prime} \mathrm{N}\right.$, $20^{\circ} 48^{\prime}$ E, Fig. 1u), Republic of Macedonia. 
101 Dorcadion (Cribridorcadion) obenbergeri Heyrovsky, 1940 from Vermio Mountains

102 (40³7’26’N, 2156’33’E, Fig. 1v), Macedonia, Greece.

103 Dorcadion (Iberodorcadion) fuliginator Linnaeus, 1758: males from Irun region (4320’ N,

$104 \quad 01^{\circ} 47^{\prime}$ W, Fig. 1m), Spain.

105 Neodorcadion bilineatum Germar, 1824: males from Mount Pelion, Thessaly (39²6’N,

$10623^{\circ} 02^{\prime}$ E, Fig. 1q) and several other places in Greece.

107 Neodorcadion exornatum: males from Microderio $\left(41^{\circ} 18^{\prime} \mathrm{N}, 26^{\circ} 01^{\prime} \mathrm{E}\right.$, Fig. 1r) Thraki, 108 Greece.

109 Parmena pubescens Dalman, 1817: one female from Methoni (36 $50^{\prime} \mathrm{N}, 2^{\circ} 40^{\prime} \mathrm{E}$, Fig. 1x)

110 Peloponisos, Greece.

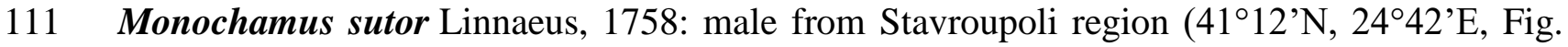

112 1y) Thraki, Greece.

113 Phytoecia (Musaria) affinis Harrer, 1784: male and female specimens from Mount Olympus $114\left(40^{\circ} 04^{\prime} 55^{\prime \prime}\right.$, $22^{\circ} 20^{\prime} 55^{\prime \prime}$ E, Fig. 1w).

116 Cytogenetic techniques

117 Proliferating cells of three origins were obtained: testicles, mid gut and eggs.

118 Testicular follicles. Follicles were extracted from the abdominal cavity. Each follicle was

119 immediately dropped into a $0.88 \mathrm{~g} / \mathrm{K} \mathrm{KCl}$ aqueous solution where it remained for $15 \mathrm{~min}$ at

120 room temperature. After centrifugation, it was transferred into a micro-centrifuge tube (VWR

121 International SAS, code 211-0033) containing a $0.55 \mathrm{~g} / \mathrm{l} \mathrm{KCL}$ solution, where it was squashed

122 and suspended using a piston (VWR, code 045520) adapted to the tube. The volume of the

123 supernatant was increased to $1.5 \mathrm{ml}$ by addition of $0.55 \mathrm{KCl}$ solution. After $10 \mathrm{~min}$, the

124 hypotonic solution was replaced by Carnoy 1 fixative where the cells were suspended and left

125 for a minimum of $30 \mathrm{~min}$. After one change of fixative (all centrifugations $5 \mathrm{~min}$ at $800 \mathrm{~g}$ ), the 
126 cells were spread on wet and cold slides. Giemsa staining, C-banding, NOR-staining were

127 performed as described (Angus, 1982, 1988, Dutrillaux et al. 2006, Howell and Black, 1980).

128 Mid-gut cells. Dissection was performed in $0.88 \mathrm{~g} / \mathrm{K} \mathrm{KCl}$. About $0.3 \mathrm{~cm}$ long fragments of mid

129 gut were cleared out of their content and put in a watch-glass containing $0.88 \mathrm{KCl}$ solution.

130 The fragments were dilacerated, one drop of colcemid solution was added and the mixture of

131 suspended cells and remaining fragments was left for one hour before being squashed and

132 treated as above, except that the $\mathrm{KCl}$ solution was replaced by fetal calf serum diluted in 133 distilled water (1 vol::2vol).

134 Eggs. The main difficulty is the choice of the best moment to obtain dividing cells. We

135 selected the period when the eggs are swelling. Eggs were cleaned up and put directly in a

136 micro-centrifuge tube containing either a $0.55 \mathrm{KCL}$ or diluted serum solution. Then, they

137 were squashed and treated as described above.

138 All karyotypes and chromosome measurements were performed using the IKAROS device 139 (METASYSTEMS, Germany).

140

141 Sequencing analysis of the mitochondrial COI gene

142 Mitochondrial DNA was isolated from 34 individuals. A $525 \mathrm{bp}$ segment at the 3' end of the 143 COI gene was amplified using the primers C1J 1718 (5'144 GgagGATtTGGAGGTtGATTAGTTCC-3') and C1N $2191 \quad$ (5'145 CCCGGTAAAATTAAAATATAAACTTC-3') (Simon et al., 1994). PCR reactions (50 $\mu$ l) 146 contained 200-500 ng DNA, $10 \times$ Taq buffer, $2 \mathrm{mM} \mathrm{MgCl} 2,0.2 \mathrm{mM}$ of each dNTP, 50

147 pmoles of each primer and $1 \mathrm{U}$ Taq polymerase (Invitrogen, Carlsbad, CA, USA). The 148 cycling conditions consisted of an initial denaturation at $95^{\circ} \mathrm{C}$ for 5 min followed by 35 cycles 149 of denaturation at $95^{\circ} \mathrm{C}$ for $30 \mathrm{~s}$, annealing at $52^{\circ} \mathrm{C}$ for $40 \mathrm{~s}$ and extension at $72^{\circ} \mathrm{C}$ for $1 \mathrm{~min}$, 150 with a final extension at $72^{\circ} \mathrm{C}$ for $10 \mathrm{~min}$. PCR products were purified using QIAquick PCR 
151 purification kit (QIAGEN Cat. No. 28106, Valencia, CA, USA) and were sequenced directly

152 and bi-directionally by Macrogen Inc. Nucleotide sequences were aligned using ClustalX

153 (Larkin et al., 2007).

154 For all haplotypes, base composition, nucleotide variation, polymorphic and parsimony

155 informative sites, the appropriate model of sequence evolution and phylogenetic associations

156 among lineages were assessed using MEGA version 5 (Tamura et al. 2011). According to BIC

157 scores (Bayesian Information Criterion) the $\mathrm{GTR}+G+I$ model [General Time Reversible

158 modeled by using a discrete Gamma distribution $(+G)$ with 5 rate categories and by assuming

159 that a certain fraction of sites are evolutionarily invariable $(+I)]$ was selected for subsequent

160 analyses and the construction of a neighbor-joining (NJ) tree. Parsimony and ML trees were

161 also constructed. Node support was assessed on the basis of 1000 bootstrap replicates. For all

162 trees, the sequence of Aegosoma scabricorne were used as outgroup.

163 A Bayesian analysis was also performed with MRBAYES version 3.1 (Huelsenbeck \&

164 Ronquist, 2001), under the HKY85 model of sequence evolution. Depending on the data set,

165 random starting trees run for $2 \times 10^{6}$ to $8 \times 10^{6}$ generations were used, sampled every 100

166 generations. Burn-in frequency was set to the first $25 \%$ of the sampled trees.

167

168 Results

169

170 Species identification. All the specimens studied here were captured by in nature. We had no

171 difficulty for determining their specific or sub-specific status, which agreed with the known

172 localities of the species, except for the two specimens of Morimus from Bourazani (Epirus,

173 Greece). Their antennae are large and the surface of their elytrons is completely granular, as

174 in $M$. asper asper, whereas the elytra pubescence is pale grey and dark spotted, as in $M$.

175 funereus. These morphologic characters correspond to those described for Morimus 
ganglbaueri Reitter, 1894. However, this species is known from Dalmatian coast (Bosnia, Montenegro and Albania), but not from Greece. Thus, if our identification is correct, this species occurs in Greece, at least in border zones with Albania. It may be also that these specimens are hybrids between M.asper and M. funereus.

Breeding assays. Morimus imagines, fed with twigs of various species of trees, can be kept alive for several months, i.e., from the month of May until March of the following year in our experience. We kept couples of $M$. funereus and one couple formed by a male $M$. asper asper and a female M. funereus captured in nature in Greece. They co-existed peacefully for months with frequent ridings, and their behaviour was similar to that of other couples. Eggs were laid 5 months later, and first instar larvae could colonise a branch of cherry-wood from Fontainebleau region (where genus Morimus does not occur). They were maintained at room temperature and a single female imago was obtained on July. Its phenotype was typically that of M. funereus, except that its dark spots were granulated, as in M. ganglbaueri and M. asper asper, and not M. funereus. Unfortunately, we did not know whether or not the female, captured in nature, was virgin. This makes uncertain the hybrid status of the descendant.

\section{Chromosomal data}

Morimus asper. Published data: none. The karyotype is composed of 22 autosomes, a submetacentric $\mathrm{X}$ and a puntiform $\mathrm{Y}: 24, \mathrm{XY}$ in the males and $24, \mathrm{XX}$ in the females. Three autosomes (1, 2 and 3) are almost metacentric and one autosome (4) is sub-metacentric, with a largely heterochromatic short arm. All other autosomes are acrocentric, with very small amounts of heterochromatin in their short arms (Fig. 2.1). This description prevails for specimens of all geographic origins in which only few variations of juxta-centromeric (Cbanded) heterochromatin were observed. The most variable segment is the short arm of 
201 chromosome 6. At the pachytene stage of meiosis, this arm is elongated, and deeply silver

202 stained indicating it harbours the Nucleolus Organizer Region (NOR). At the first meiotic 203 division, there are 11 autosomal bivalents and the sex bivalent has a parachute configuration: $20411+$ Хур.

205 Morimus ganglbaueri. Published data: none. The karyotype is fairly similar to that described 206 above: $24, \mathrm{XY}$ and $24, \mathrm{XX}$ in the male and female, respectively(Fig. 2.2). Heterochromatin is 207 slightly more intensely C-banded and may be present in intercalary position of some 208 chromosomes.

209 Morimus funereus. Published data: description of a disomy Y: 25,XYY (Dutrillaux and 210 Dutrillaux, 2011). The karyotype, similar in specimens from the different localities, does not 211 look different from that of the previous taxa: $24, \mathrm{XY}$ and $11+\mathrm{Xyp}$ in the males. Intercalary 212 heterochromatin is occasionally present (chromosome 5, 7) (Fig. 2.3).

213 Herophila tristis. Published data: none. Its karyotype is also composed of 24 chromosomes 214 (24,XY in the males), but compared to that of Morimus species, only 2 pairs of autosomes are 215 metacentric (Fig. 2.4). The 2 largest pairs of acrocentrics carry large and variable amounts of 216 heterochromatin, one of them harbouring the NOR. Pair 6 is acrocentric and harbours 217 heterochromatin in its long arm. Finally, the $\mathrm{X}$ chromosome is acrocentric and not sub218 metacentric.

219 Herophila fairmairei. Published data: none. Its karyotype is similar to that of $H$. tristis: $22024, \mathrm{XX}$ for the females, but the amounts of heterochromatin on the 2 pairs of large acrocentrics 221 are yet more important (Fig. 2.5). Thus, the amplification of heterochromatin on chromosome 2223 and 4 may be a characteristic of the genus Herophila.

223 Lamia textor. Published data: none. Its karyotype is composed of 22 chromosomes only, but 224 one pair $\left(\mathrm{N}^{\circ} 8\right)$ is either dicentric or pseudodicentric, so that the number of C-banded 225 "centromeres" is the same as in Morimus species (Fig. 2.6). Unfortunately, we could not get 
males, and female karyotypes did not allow us to identify with certainty the X chromosomes.. The size and morphology of autosomes recall those of Morimus, but the presence of 4 metacentrics suggests that at least 2 inversions separate their karyotypes.

Dorcadion (Cribridorcadion) thessalicum. Published data: none. Its karyotype is composed of 22 autosomes, including 2 metacentrics, an acrocentric $\mathrm{X}$ and a punctiform $\mathrm{Y}: 24, \mathrm{XY}$ in the male (Fig. 2.7).

Dorcadion (Cribridorcadion) equestre. Published data: none. Its karyotype is composed of 24 chromosomes, including 2 pairs of metacentrics, a sub-metacentric $\mathrm{X}$ and a punctiform $\mathrm{Y}$ : 24,XY in the male (Fig. 2.8). The NOR is located on the sub-centromeric position of an acrocentric, probably $\mathrm{N}^{\circ} 6$ or 7 .

Dorcadion (Cribridorcadion) obenbergeri. Published data: none. Its karyotype is composed of 20 autosomes, a metacentric $\mathrm{X}$ and an acrocentric $\mathrm{Y}$ (Fig. 2.9). The reduction of the number of autosomes and the enlargement of the sex chromosomes are the consequence of a translocation (fusion) between the $\mathrm{X}$ proper and an autosome. Thus, the $\mathrm{X}$ is a neochromosome. Its short arm is formed by the ancestral X, and its long arm is formed by an ancestral acrocentric, whose size corresponds to $\mathrm{N}^{\circ} 6$ or 7 in other species of Dorcadion. The neoY is probably entirely composed by this autosome. This translocation is a synapomorphy. Dorcadion (Iberodorcadion) fuliginator. Published data: none. The number and morphology of its chromosomes are quite similar to that $D$. equestre, except for the $\mathrm{X}$, which is acrocentric: 24,XY. After C-banding, most chromosomes exhibit, in addition to the centromeric bands, one or 2 bands located in intercalary or terminal position of the chromatids (Fig. 1.10). These variable additions of heterochromatin were found in the 3 males studied.

Neodorcadion bilineatum. Published data: none. Its karyotype is composed of 22 autososomes, with 2 pairs of metacentrics and one pair of sub-metacentric. Chromosome $\mathrm{X}$ is sub-metacentric and the $\mathrm{Y}$ is punctiform: 24,XY in the males (Fig. 2.11). 
251 Neodorcadion exornatum. Published data: none. Its karyotype is also composed of 22 252 autosomes with 2 pairs of metacentrics. The $\mathrm{X}$ is sub-metacentric and the $\mathrm{Y}$ has a 253 heterochromatic short arm: 24,XY. Thus, the karyotypes of the 2 species of Neodorcadion 254 differ by at least one peri-centric inversion. In the female studied, there was an additional B 255 chromosome (Fig. 2.12).

256 Parmena novaki. Published data: none. Its karyotype is composed of 20 chromosomes, all 257 meta- or submetacentric of progressively decreasing size: 20,XX in the single female studied 258 (Fig. 2.13). The C-banding is limited to the centromeric region.

259 Monochamus sutor. Published data: Teppner (1966), Abe et al. (1971), Kudoh et al. (1972), 260 Cesari et al. (2005) and Dutrillaux and Dutrillaux (2014). The karyotype is composed of 18 261 autosomes, all meta- or sub-metacentric. The $\mathrm{X}$ chromosome is sub-metacentric and the $\mathrm{Y}$ is 262 punctiform: 20,XY in the males (Fig. 2.14). The NOR is sub-centromeric on chromosome 7. 263 There is a size hiatus between chromosomes 1 and 2.

264 Phytoecia affinis. Published data: none. Its karyotype is composed of 20 chromosomes, all 265 the autosomes are either metacentric or sub-metacentric of progressively decreasing size: $26620, \mathrm{XY}$ in the males and 20,XX in the females (Fig. 2.15). The short arm of the $\mathrm{X}$ is largely 267 heterochromatic.

\section{Nucleotide analysis and phylogenetic reconstruction}

270 Sequences obtained, primers excluded, corresponded to a $525 \mathrm{bp}$ segment. The absence of 271 insertions, deletions or in-frame stop codons within the sequences studied indicated that they 272 correspond to functional mitochondrial COI gene fragments and are not derived from nuclear 273 mitochondrial pseudogenes (numts), commonly occur in most eukaryotic species (Richly \&

274 Leister, 2004; Cameron et al., 2009). Haplotypes were evaluated and compared to. All 275 haplotypes, after evaluation and comparison to published sequences in Genbank, 
corresponded to new sequences and thus were submitted to GenBank with accession numbers: MH613717- MH613750.

The high percentage ( $64.7 \%$ on average) observed for the $\mathrm{A}+\mathrm{T}$ content, is a common feature of animal mitochondrial genes (Brown, 1985). Out of the 525 sites, 196 were variable while 168 of them were informative for parsimony. Net genetic distances between species ranged from $1.8 \%$ (M. asper - M. funereus) to 26.3\% (Monochamus sutor-Dorcadion bilineatum). Nucleotide divergence within $M$. asper and M. funereus were $1.2 \%$ and $0.2 \%$, respectively. With some minor differences, the phylogenetic trees based on the Bayesian analysis (tree not shown, available on request), as well as on pairwise haplotype divergence (NJ) (fig. 3), showed similar topologies. The main branches exhibited high bootstrap values (NJ) and high posterior probabilities (Bayesian analysis).

\section{Discussion}

\section{Chromosome comparisons and evolution.}

In Cerambycidae, as in Polyphagan Coleoptera in general, the most frequently reported karyotype formulae are 20,XY and 20,XX, in males and females, respectively, with all or almost all chromosomes metacentric or sub-metacentric (Smith and Virkki, 1978, Dutrillaux and Dutrillaux, 2009). Such karyotypes were observed in most of the tribes of Lamiinae we studied. In our yet unpublished data base, we found it in at least one species of the following tribes: Acanthocini, Acanthoderini, Agapanthini, Desmiphorini, Mesosini, Monochamini, Onciderini, Phytoeciini, Pteropliini, and Saperdini. Thus, it is assumed to represent the ancestral condition, but some variations exist. They consist in an increase of chromosome number to 22, rarely more, generally accompanied by the presence of acrocentrics, which suggests that fissions of the metacentrics occasionally occurred during evolution. In the group 
of 15 species/sub-species studied here, $P$. novaki and $P$. affinis have conserved a karyotype with 20 chromosomes of progressively decreasing size, probably close to that of the ancestor. With its very large chromosome 1 , the karyotype of $M$. sutor is probably derived by a translocation, but it conserved the number of 20 chromosomes. All but 2 of the 12 other species studied here have 24 chromosomes. The10 karyotypes with 24 chromosomes, which look not much different from each others, may derive from the primitive situation by the fission of 2 metacentrics, which formed 4 acrocentrics. However, their high number of acrocentrics ( 7 to 9 ) implies that 3 to 5 peri-centric inversions also occurred. The karyotype with 22 chromosomes of $D$. obenbergeri, obviously apomorphic, derives from that of other Dorcadion by a gonosome-autosome translocation. On the whole, the chromosome rearrangements, which originated the resembling karyotypes of genera Morimus, Herophila and Dorcadion, very probably occurred in common ancestors. Thus, these genera form a monophyletic group. The chromosomal relationships between Lamia textor and others are less obvious. The karyotype of this species, with 22 chromosomes, looks intermediary between those of the groups with 20 and 24 chromosomes, but one pair looks dicentric, or pseudodicentric, as defined in ISCN (1985), with 2 primary constrictions and 2 C-bands (Fig. 2.6). Thus, it has 24 potential centromeres, and may derive by a termino-terminal fusion of 2 acrocentric chromosomes from a karyotype with 24 chromosomes. Because of the frequent involvement of the $\mathrm{X}$ chromosome in translocations in Coleoptera (Dutrillaux and Dutrillaux, 2009), as here in D. obenbergeri, it is possible that the proper $X$ forms one arm of this pseudo-dicentric.

In conclusion, the lack of available probes makes impossible to perform a precise chromosome identification by in situ hybridization, and thus, to reconstruct a phylogeny by chromosome comparison. Nevertheless, the great resemblance of their karyotypes are strong arguments in favor of a monophyletic origin of genera Morimus, Herophila, Dorcadion and 
Lamia, which share similar derived features compared to other Lamiinae. At difference, the karyotypes composed of 20 chromosomes, here observed in P.novaki, M. sutor and P. affinis share many features, with many other Cerambycids. We conclude that they underwent few gross chromosome changes during evolution.

\section{CO1 sequence comparisons}

In a recent study Solano et al. (2013) analysed 65 specimens of M. funereus sampled in Italy, Balkans and Turkey by applying COI and ITS2 molecular markers. Unfortunately, although they found 39 haplotypes for COI, the overlap between this set of sequences and ours was practically nonexistent (of approximately 10 nucleotides), making it impossible to compare between them. However, a striking difference between the two studies was the 10-fold higher nucleotide diversity assessed for $M$. funereus $(\pi=0.0226)$ in comparison to our data $(\pi=$ 0.002). A possible explanation for this discrepancy could be the much larger range of sampling in the study of Solano et al. (2013).

Sequencing does not contradict chromosome data, but it provides a better resolution. Species belonging to the various tribes of Lamiinae are well separated, and there is a common trunk for genera Morimus, Lamia, Herophila and Dorcadion. The splitting of Dorcadion in Iberodorcadion, Neodorcadion and other Dorcadion will be discussed elsewhere, with the study of many more species. The 2 species of Herophila are monophyletic, and also well individualised. $\mathrm{CO} 1$ sequences of specimens of $H$. fairmairei, a rare and very localised species, appear to be fairly close to each other, while those of $H$. tristis, a largely spread species, are more diverse. Thus, both bio-geographic and genetic data suggest that $H$. fairmairei may be a localised vicariant of $H$. tristis.

The genus Morimus is fairly homogeneous, although separated into two groups, with M. asper on one side and M. funereus and M. ganglbaueri on the other side. CO1 sequences did not 
accumulate many mutations separating French and Greek specimens of M. asper. The position of the French specimens of $M$. asper in the cladogram is among the most derived one. This is compatible with a radiation of the genus Morimus from Balkans, or more oriental countries, to western countries such as France and Spain, which would be the extremity of the radiation and the most recently colonised countries. The similarity of haplotypes found in $M$. ganglbaueri and M. funereus is interesting. M. ganglbaueri shares rather more morphological characters with $M$. asper (long antennas and granulation of elytra), than with $M$. funereus (density and colour of pilosity). By these mixed characters and its geographic repartition, surrounded by that of $M$. funereus on the East and $M$. asper, on the South and West, $M$. ganglbaueri might have a hybrid origin. In this hypothesis, the similarity of mitochondrial CO1 sequence with $M$. funereus could indicate that this species was originally the maternal contributor. Our breeding experiments show that hetero-specific couples can occur, but we could not formally demonstrate their fertility.

As suggested by chromosome data, the CO1 sequence places Lamia textor within the group Morimus, Herophila and Dorcadion, far from other taxa. More precisely, L. textor looks very close to Dorcadion.

\section{Comparison between $\mathrm{CO} 1$ and chromosomal data}

There is no major discrepancy between the two sets of data, but the mutations of the CO1 sequence are much more discriminating than the alterations of chromosomes for establishing a phylogeny. Thus, it was possible use the cladogram obtained with CO1 analysis for indicating the minimum number of chromosome rearrangements necessary to pass from one karyotype to another (Fig. 3). The maximum number of chromosome changes should have occurred in the common trunk for Morimus, Herophila, Lamia and Dorcadion, which fits 
376 with CO1 data. It persists however 2 major questionings: 1) D.I. fugilinator has the same 377 karyotype than the other species of Dorcadion, if we omit heterochromatin variations, 378 although $\mathrm{CO} 1$ data place it near Herophila. The explanation may be that the karyotype of 379 Dorcadion is also that of the ancestors of both Herophilus and Morimus, but the study of 380 more species of Iberodorcation is necessary for more supported conclusions. 2) CO1 data

381 place $L$. textor near Dorcadion whereas its karyotype seems to have conserved more ancestral 382 features. The 2 inversions indicated after bifurcation (Fig. 3) could be reverse, but 383 chromosome interpretation would be simpler if $L$. textor was branched between bifurcations c 384 and $d$ before the acquisition of 2 of the 4 inversions. The study of more specimens, males in 385 particular, is urgently needed. By evaluating the convergence of chromosomal and molecular 386 data, we believe that, despite its limitations when applied solely (e.g. selective sweeps, 387 inability to identify hybridization), the $\mathrm{CO} 1$ marker provides the required signal to reconstruct 388 the phylogenetic relationships between the genera under study. In the last decade, there is 389 growing evidence about the importance of the CO1 gene and its unique barcoding attributes 390 are believed to have arisen from its implication to the process of speciation (Gershoni et al, 391 2009). The species-specific mitonuclear coadaptations that occur to maintain the functionality 392 of the Oxidative Phosphorylation are thought to be a major force of speciation (Lane, 2009). 393 The CO1 gene possesses a "special place" in the above mentioned since it encodes for a 394 catalytic subunit of cytochrome c oxidase, which is a key OXPHOS regulator (Hill, 2016). As 395 he proposes: “...it is no coincidence that the rate-controlling gene in the ECT that can enable 396 respiratory adaptation to novel environments is also an effective DNA barcode for animals."

\section{Conclusion}

399 The comparisons of CO1 mitochondrial gene sequences and karyotypes give convergent data, 400 which indicate an undisputable monophyletic origin of genera Morimus, Herophila, Lamia 
401

402

403

404

405

406

407

408

409

410

and Dorcadion, at a large phylogenetic distance from other genera such as Monochamus. This does not support classifications, which put together Lamia and Monochamus in a same tribe, whatever its name Monochamini, Lamiini or Agniini. The nomenclature problem seems to be historical: Lamia, considered as the genus type of Lamiinae, logically should remain in the Lamiini tribe. It should better have been grouped with Dorcadion (Dorcadionini) and Morimus/Herophila (Phryssomini), but instead, it has been always grouped with many other taxa, such as Monochamus, which have very loose phylogenetic relationships. Thus, two options can be proposed: either Lamia with only a few closely related genera remain in a restricted Lamiini tribe, or the tribes Phryssomini and Dorcadionini are suppressed and their species join these few lamiini to form a monophyletic new Lamiini tribe. This would provide a logical basis for further classifications

Figures captions

\section{Figure 1}

Map of Greece with indications by letters of the places of sampling. The letters correspond to those indicated in the cladogram of figure 3: a-f: M. asper; g-k: M. funereus; $1: M$. ganglbaueri; m: D.I. fuliginator; n,o: H.tristis; p: H. fairmairei; q: Neodorcadion bilineatum; r: Neodorcadion exornatum; s: L. textor; t: D. C. thessalicum; u: D. C. equestre; v: D.C. obenbergeri; w: P. affinis; x: P. novaki; Y: M. sutor.

\section{Figure 2}

Karyotypes after Giemsa staining (13) or C-banding (all others). 1: $M$. asper; 2: $M$. ganglbaueri; 3: M. funereus; 4: H. tristis; 5: H. fairmairei; 6: L. textor; 7: D. C. thessalicum; 8: D. C. equestre; 9: D. C. obenbergeri; 10: D. I. fuliginator; 11: N. bilineatum; 12: N. exornatum; 13: P. novaki; 14: M. sutor; 15: P. affinis. 
426

427

428

429

430 431 heterochromatin addition.

\section{Figure 3} 183. https://doi.org/10.1080/01650428809361325

448

449 Bousquet, Y., Heffern, D.J., Bouchard, P., \& Nearns, E.H. (2009) Catalogue of family-group 450 names in Cerambycidae (Coleoptera). Zootaxa, 2321, 1-80.

Phylogenetic tree constructed with the NJ algorithm. Small letters on the left correspond to specimens collected at the locations indicated at Figure 1. Chromosome rearrangements separating the karyotypes are indicated but were not considered to establish the tree. F:fission; I: pericentric inversion, $\mathrm{T}$ : translocation; $\mathrm{D}$ : Dicentric or pseudodicentric; $\mathrm{H}$ : large

\section{References}

Abe A, Kudoh K, Saito K. (1971) Chromosome study of beetles III: A chromosome survey of 18 species of the sub-family Lamiinae (Cerambycidae). Sci Rep Hirosaki Univ 18: 53-63.

Angus, R. B (1982). Separation of two species standing as Helophorus aquaticus (L.) (Coleoptera, Hydrophilidae) by banded chromosome analysis. Systematic Entomology, 7(3), 265-281. https://doi.org/10.1111/j.1365-3113.1982.tb00444.x

Angus, R. B. (1988). A new sibling species of Helophorus f. (Coleoptera: Hydrophilidae), revealed by chromosome analysis and hybridisation experiments. Aquatic Insects, 10(3), 171- 
452 Cesari, M., Marescalchi, O., Francardi, V. \& Mantovani, B. (2005): Taxonomy and 453 phylogeny of European Monochamus species: first molecular and karyological data. - Journal 454 of Zoological Systematics and Evolutionary Research 43 (1): 1-7.

456 Dutrillaux A-M, Dutrillaux B(2009). Sex chromosome rearrangements in Polyphaga beetles. 457 Sex Development 3: 43-54

458

459 Dutrillaux AM, Dutrillaux B. (2011). Y-chromosome disomy and trisomy in Scrabaeid and 460 Cerambycid beetles. Cytogenet Genome Res 132: 195-202.

461 Dutrillaux AM, Dutrillaux B. (2014). Chromosome evolution of some Palaearctic species of 462 Monochamus (Coleoptera : Cerambycidae : Lamiinae). Ann Soc Entomol Fr (N.S.). 50 : 213 463 218. http://dx.doi.org/10.1080/00379271.2014.937599

464 Gershoni M., Templeton A.R., Mishmar D. (2009). Mitochondrial bioenergetics as a major 465 motive force of speciation. Bioessays. 31(6):642-50.

466 Hill G. (2016). Mitonuclear coevolution as the genesis of speciation and the mitochondrial 467 DNA barcode gap. Ecology and Evolution. 6(16): 5831-42

468 Kudoh K, Abe A, Saito K. (1972). Chromosome studies in beetles.V: Male germ 469 cellschromosomes of two species of the genus Monochamus (Cerambycidae)Sci Rep Hirosaki $470 \quad$ Univ $19: 15-18$

471 Lane, N. (2009). On the origin of bar codes. Nature 462: 272- 274.

472 Monne M.L., Monne M.A. \& Wang Q. (2017). General morphology, classification and 473 biology of Cerambycidae. In Wang Q. (Ed.): Cerambycidae of the World. Biology and Pest 
474 Management. CRC Press, Boca Raton, London, New York, pp. 1-70.

475 Löbl I., Smetana A. (2010). Catalog of Palaearctic Coleoptera, vol. 6. Chrysomeloidea. 476 Stenstrup, Apollo books. 924 pp.

477 Okutaner A. Y, zdjikmen H., Yûksel E., Koçak Y. (2011) Some cytogenetic observations of 478 Morimus orientalis Reitter, 1894 (Coleoptera : Cerambycidae : Lamiini : Lamiini). Munis 479 Entomology \& Zoology 6 : 912-919.

480 Smith S.G. \& Virkki N. (1978). Animal Cytogenetics, Vol. 3 Insecta 5 Coleoptera. Gebrûder 481 Borntraeger, Berlin, pp 236-290.

482 Teppner H. (1966). Chromosomenzahlen einiger mitteleuropäischer Cerambycidae 483 (Coleoptera). Chromosoma (Berl.) 19: 113-125.

484

485

486 
$487 \quad$ Figure 1

488

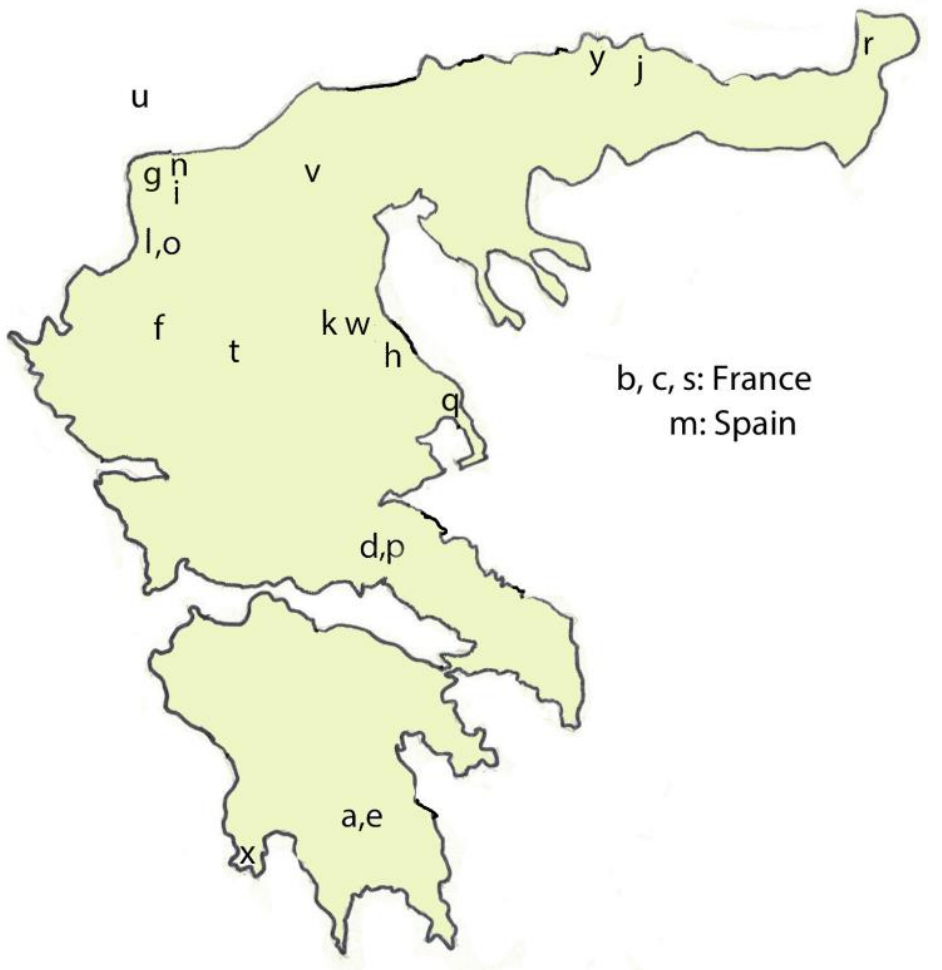

489 
Figure 2

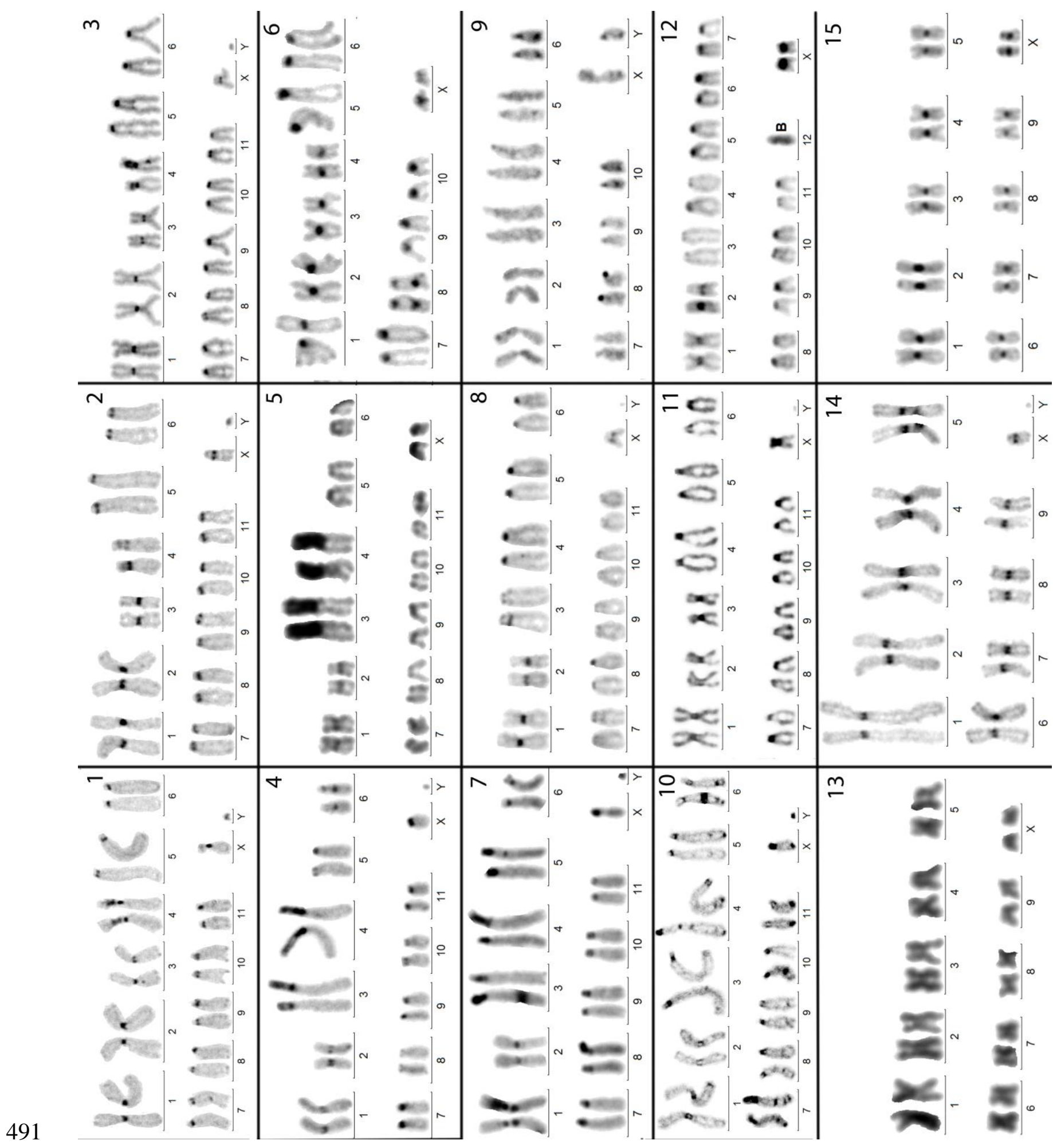


$493 \quad$ Figure 3

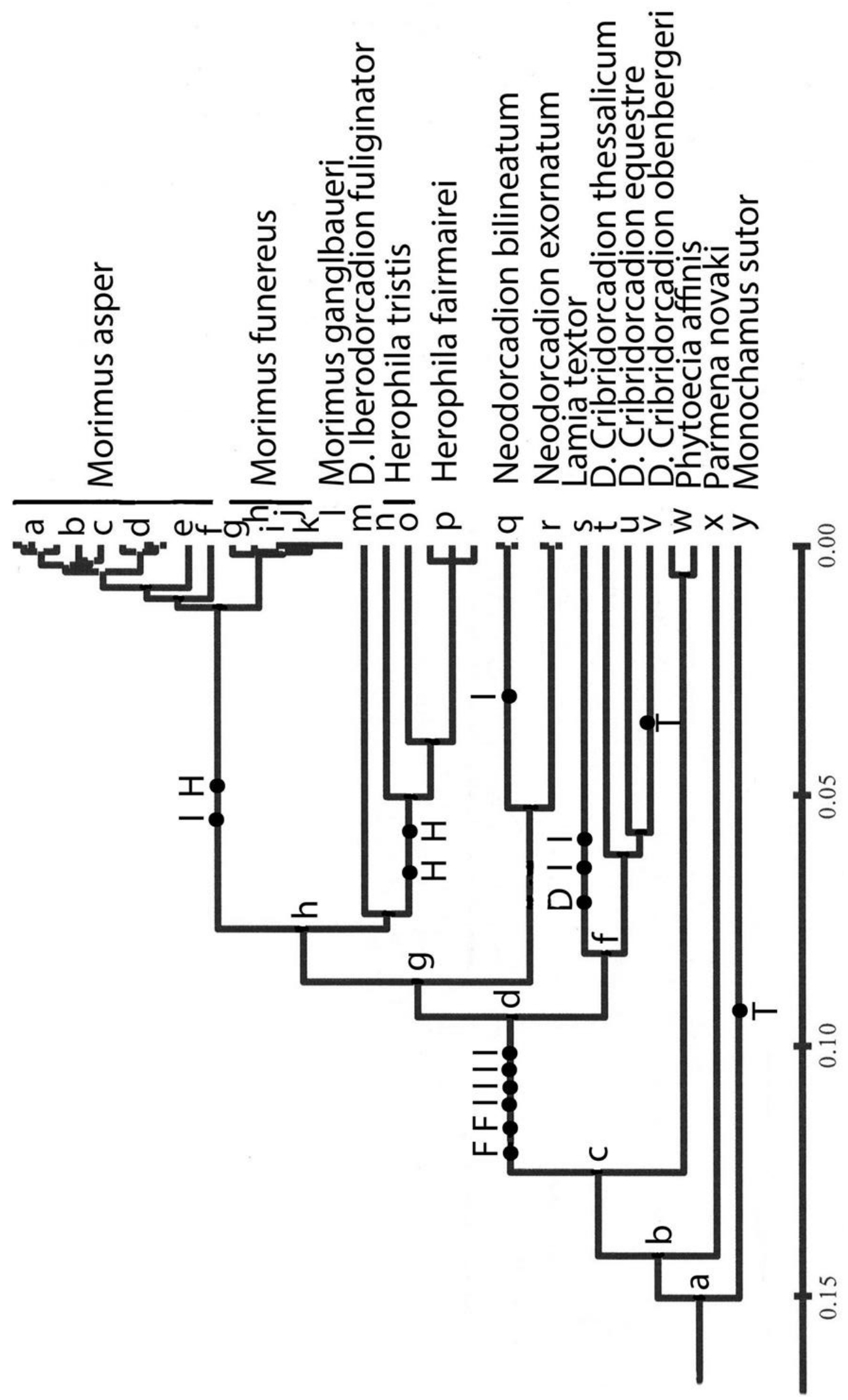

